\title{
Az Amalgerol talaj- és növénykondicionáló preparátum hatása nagy sótartalmú talajon, monokultúrás paprikahajtatásban
}

\author{
${ }^{1}$ NÉmEth Tamás, ${ }^{2}$ Horváth József és ${ }^{3}$ KuCsERA Sándor \\ ${ }^{1}$ Egyéni vállalkozó, Sárszentmihály \\ ${ }^{2}$ Cheminova FMC Magyarország, Budapest \\ ${ }^{3}$ NÉBIH Növény-, Talaj- és Agrárkörnyezet-védelmi Igazgatóság \\ Velencei Talajvédelmi Laboratórium, Velence
}

\section{Bevezetés}

A zöldségtermesztésben az intenzív kemikáliahasználat következtében egyre jobban fokozódik a talajok kémiai és biológiai degradációja, mindezek okán csökken a termékenysége. A túlzott mütrágyahasználat számos toxikológiai problémához vezethet (ZAIDI et al., 2015). A nagy sótartalom káros hatásából adódóan a zárt terek alatti zöldségtermelés egyre nehézkesebb (SHANNON \& GRIEVE, 1998). A kedvezőtlen hatások kiküszöbölése érdekében egyre nagyobb hangsúlyt kapnak a természetes eredetű készítmények. A biostimulátorok fokozzák a növény életfolyamatait, illetve kedvező feltételeket teremtenek a talajban lévő mikroorganizmusoknak (HECKMAN, 1993; NARDI et al., 2009). A preparátumokban lévő természetes komponensek kedvező hatást fejthetnek ki a növények termésprodukciójára és a természetes ellenálló-, illetve sótürö képességére.

DERKOWSKA és munkatársai (2015) számos biopreparátum hatékonyságát vizsgálta. Tapasztalataik szerint a kezelések hatására az arbuszkuláris mikorrhiza gombák (AMF) spóraszáma és a mikorrhizás növények gyakorisága is növekedett. A mikorrhiza gombák előnyös hatásáról viszonylag nagy irodalmi anyag áll rendelkezésre. MARSCHNER és DELL (1994) vizsgálatai szerint a mikorrhiza gombával kezelt növények $80 \%$-kal több foszfort, és $25 \%$-kal több nitrogént vettek fel a kontrollhoz képest.

SMITH és READ (1997) szerint a foszfor felvétele akár 100\%-al is nagyobb lehet. TAKÁCS és munkatársai (2006) szerint a mikorrhizális (AMF) kapcsolatok a legmeghatározóbbak a növény foszforfelvételében. E kapcsolat révén a növény olyan tápanyagokhoz is hozzájut, amely egyébként számára elérhetetlen, ilyenkor a növény általános ellenálló képessége jelentősen megnő. Az AMF kapcsolatok alkalmazása BAUM és munkatársai (2015) szerint hatékony a szárazság és a só-stressz elleni tolerancia növelésében. Az AMF kapcsolatok arid (száraz) körülmények közt FÜZI és munkatársai (2008) szerint is meghatározó jelentőségüek.

Postai cím: NÉMETH TAMÁS, egyéni vállakozó, 8143 Sárszentmihály, Dózsa György. u. 17.E-mail:ntamas27@gmail.com 
DAVIES és munkatársai (1992) vizsgálatai szerint a mikorrhiza gombával kezelt paprika szárazságtürése növekedett. CORDIER és munkatársai (1998), valamint POZO és AzCóN-AGUILAR, (2007) szerint a mikorrhizás növény nagyobb ellenállóságot mutat a talajeredetü kórokozókkal szemben. WHIPPS (2004) szerint a mikorrhizák hatékonyak (Sclerotinia cepivorum, Fusarium oxysporum, Verticullium dahliae, Rhizoctonia solani, Phytophthora capsici) a patogének ellen.

A kereskedelmi forgalomban számos olyan készítmény elérhető, amellyel fokozható a talajban lévő mikroorganizmusok tevékenysége. RICHTER és munkatársai (2005) szerint az Amalgerol (Hechenbichler GmbH, Ausztria) preparátum aktivizálja a talajban lévő hasznos mikrobákat. Hasonló tapasztalatokról ír CACIKOVA (1997), Elena és Vytautas (2013), illetve PARÁDI és munkatársai (2014) is. PARÁDI és munkatársai (2014) szerint a preparátum fokozza a talaj életközösségének növények számára előnyös müködését. A szerzők azt is feltételezik, hogy a preparátum-kezelések és a mikorrhiza gombák között szinergista kapcsolat áll fent.

DoBos és munkatársai (2011) szerint az Amalgerol termésnövelő anyagként is hatékony a burgonyatermesztésben. ŠIMUNIĆ és munkatársainak (2011a) vizsgálati eredményei szerint a preparátum növelte a burgonya átlagtermését. Kedvező eredményekröl számoltak be ELENA és munkatársai (2013) is, akik cukorrépán végeztek vizsgálatokat. KOSTADINOVA és munkatársai (2015), valamint RICHTER és munkatársai (2002) őszi búzán tesztelték a készítményt. Megfigyeléseik alapján a kezelések pozitívan befolyásolták a termésprodukciót. DelCHEV és STOYANOVA (2013) szerint a kezelések jó hatásúak a búza bokrosodására és a növekedésére. RICHTER és munkatársai (2002), illetve FORA és munkatársai (2015) az őszi káposztarepcén figyeltek meg termésnövekedést. ŠIMUNIĆ és munkatársai (2011b) a szójánál hozamnövekedésről ír, azonban MILEV és TODOROVA (2014) szerint a készítmény alkalmazása a szója termésnövelésére kevésbé hatékony.

RICHTER és munkatársai (2002) az Amalgerol talajra gyakorolt hatását vizsgálta szőlő kultúrában. A kezelések után hosszútávon növekedett a talaj P-, Ca-, Mg- és K-tartalma. BOTEVA (2014) megfigyelései szerint a preparátum paprikán növelte a bogyók átlagtömegét. PULK (2015) vöröshagymán vizsgálta a készítmény hatékonyságát. Tapasztalatai alapján a kezelések alig növelték a hozamot, azonban a hagymatermések nagysága szignifikánsan növekedett. PARÁDI és munkatársai (2014) paradicsom és uborka növényeken tesztelték a preparátumot. Kutatásuk eredménye szerint a készítmény kedvező hatású a növényi növekedésre, a vegetatív és a generatív tömegre. A preparátum a szerves anyagban szegény, továbbá kevésbé aktív mikrobiális életközösségü talajokon alkalmazva hozzájárul a kiegyensúlyozott talajélet visszaállításához, következésképp természetbarát növényi stresszcsökkentést tesz lehetővé.

Hajtatásban az ültetésforgó sokszor nehézkes megvalósíthatósága indokolttá teheti a nagy sótartalmú talajokon a paprikatermesztést. Kutatásunk célja az Amalgerol biostimulátor hatékonyságának vizsgálata, nagy sótartalmú talajon termesztett paprikán, monokultúrás termesztésben. 2011-2013 között elvégezett vizsgálatok során figyelemmel kísértük a készítmény talajra, valamint a növényre gyakorolt hatását, majd 2014-ben vizsgáltuk a termék utóhatását is. A preparátum hatékonyságát több szempont szerint értékeltük: in vitro (laboratóriumban), illetve in vivo 
körülmények között (hideghajtatás). Laboratóriumi körülmények között a talaj só-, humusz-, kalcium-karbonát-, nátrium-, valamint tápanyagtartalmát, a hajtatás során pedig a növény termőképességét és a termések minőségét vizsgáltuk.

\section{Anyag és módszer}

A kutatásunkhoz felhasznált Amalgerol, talaj- és növénykondícionáló készítmény növényi illó-, valamint ásványi olajokat, alginátot, mannitolt, laminarint, alga kivonatokat, továbbá makro- és mikroelemeket tartalmaz (HALLER, 2015). A preparátum hatékonyságának felméréséhez, a fehér termésü étkezési paprikát (Capsicum annuum var. grossum) választottuk. 2011-ben a Dimentio, 2012-ben a Carma, majd 2013-ban az Etele fajtákkal dolgoztunk. Az in vitro laboratóriumi vizsgálatokat, Velencén, a Nemzeti Élelmiszerlánc-biztonsági Hivatal Növény-, Talaj- és Agrárkörnyezet-védelmi Igazgatóság Velencei Talajvédelmi Laboratóriumában, az in vivo vizsgálatokat Sárszentmihályon végeztük. A biostimulátor felhasználásával kifejezetten a lecsökkent termőképességű talajokban rejlő potenciált kívántuk felmérni. Ezért a kísérlethez olyan területet választottunk, ahol a paprikát kedvezőtlen körülmények között nagy sótartalmú, szerves anyagban szegény talajon, monokultúrában hajtatják. A területet éveken keresztül szerves trágyák felhasználása nélkül hasznosították. A kísérlethez két kezelést - preparátummal kezelt, illetve kezeletlen kontroll - állítottunk be, fütetlen fóliasátorban. Az ismétléseket 2011-ben random elrendezés szerint állítottuk be, azonban - a megfelelő nyomon követhetőség érdekében- az ezt következő évek után a kezelt és a kontroll ismétlések helyeit nem változtattuk. A kísérletet, valamint az ismétlések (parcellák) számát az 1. táblázat szerint állítottuk be. A tápkockás palántákat május első dekádjában ültettük. Az ültetések után a preparátumot egyszeri beöntözéssel juttattuk a talajba, majd a további kezelések többszöri lombtrágyázással történtek. A preparátumot a talajba öntözéskor 2011-ben $0,8 \mathrm{ml} \cdot \mathrm{m}^{-2}$, majd 2012-ben $1,5 \mathrm{ml} \cdot \mathrm{m}^{-2}$, végül 2013-ban $0,51 \cdot \mathrm{m}^{-2}$ a dózisban alkalmaztunk.

1. táblázat

A kísérlet során alkalmazott paraméterek (Sárszentmihály)

\begin{tabular}{|c|c|c|c|c|c|c|}
\hline \multirow[t]{2}{*}{$\begin{array}{l}(1) \\
\text { Év }\end{array}$} & \multirow[t]{2}{*}{$\begin{array}{c}\text { (2) } \\
\text { Kezelés }\end{array}$} & $\begin{array}{l}\text { (3) } \\
\text { Sürüség }\end{array}$ & $\begin{array}{c}\text { (4) } \\
\text { Sor és } \\
\text { tőtávolság }\end{array}$ & $\begin{array}{c}\text { (5) } \\
\text { Parcellák } \\
\text { száma }\end{array}$ & $\begin{array}{l}\text { (6) } \\
\text { Parcellánkénti } \\
\text { növényszám }\end{array}$ & $\begin{array}{c}\text { (7) } \\
\text { Terület/ismétlés }\end{array}$ \\
\hline & & $\mathrm{db} \cdot \mathrm{m}^{-2}$ & $\mathrm{~cm}$ & $\mathrm{db}$ & $\mathrm{db}$ & $\mathrm{m}^{2}$ \\
\hline 2011 & $\begin{array}{l}\text { a) Kezelt } \\
\text { b) Kontroll }\end{array}$ & 5 & $71-50 \times 33$ & 4 & 17 & 3,37 \\
\hline 2012 & $\begin{array}{l}\text { a) Kezelt } \\
\text { b) Kontroll }\end{array}$ & 3,7 & $114-50 \times 33$ & 6 & 10 & 2,7 \\
\hline 2013 & $\begin{array}{l}\text { a) Kezelt } \\
\text { b) Kontroll }\end{array}$ & 4,8 & $76-50 \times 33$ & 6 & 12 & 2,5 \\
\hline
\end{tabular}


2. táblázat

A kijutatott tápelemek mennyisége (Sárszentmihály)

\begin{tabular}{|c|c|c|c|}
\hline \multirow{2}{*}{$(1)$} & \multicolumn{3}{|c|}{ Hatóanyag } \\
\cline { 2 - 4 } Ev & \multicolumn{3}{|c|}{$\mathrm{g} \cdot \mathrm{m}^{-2}$} \\
\cline { 2 - 4 } & $\mathrm{N}$ & $\mathrm{P}$ & $\mathrm{K}$ \\
\hline 2011 & 20 & 2 & 24 \\
2012 & 16 & 1 & 14 \\
2013 & 21 & 1 & 18 \\
\hline
\end{tabular}

Permettrágyaként a termékből 2011-ben $1,7 \mathrm{ml} \cdot \mathrm{m}^{-2}$, 2012-ben $1,5 \mathrm{ml} \cdot \mathrm{m}^{-2}$, majd 2013-ban $1,4 \mathrm{l} \cdot \mathrm{m}^{-2}$ mennyiségeket használtunk. A növények tápanyagigényét tápoldatozással elégítettük ki, vízben maradék nélkül oldódó mütrágyák felhasználásával. A makroelem hatóanyagokból a 2. táblázatban közölt mennyiségeket adagoltuk ki. A felhasznált hatóanyagokat több részletben elosztva juttattuk ki. A vizsgálatban mikroelemekkel és szerves anyagokkal sem trágyáztuk a talajt. A vizsgálat során egységes fitotechnikai munkákat hajtottunk végre.

\section{3. táblázat}

A talajvizsgálat során alkalmazott vizsgálati módszerek

\begin{tabular}{|c|c|c|c|}
\hline $\begin{array}{l}\text { (1) } \\
\text { Vizsgált talaj- } \\
\text { tulajdonság }\end{array}$ & $\begin{array}{c}(2) \\
\text { Módszer }\end{array}$ & $\begin{array}{c}\text { (3) } \\
\text { Készülék }\end{array}$ & $\begin{array}{c}(4) \\
\text { Bizonytalanság }\end{array}$ \\
\hline a) Összes só & MSZ 08-0206-2: 1978 & $\begin{array}{c}\text { Konduktométer, Radelkis } \\
\text { OK-102/1 }\end{array}$ & $5-7,5$ rel.\% \\
\hline $\begin{array}{l}\mathrm{CaCO}_{3} \\
\text { b) Humusz }\end{array}$ & $\begin{array}{c}\text { MSZ 08-0206-2: } 1978 \\
\text { MSZ-08-0452: } 1980\end{array}$ & $\begin{array}{l}\text { Kalciméter, Labor MIM } \\
\text { Spectronic Genesys } 5\end{array}$ & $\begin{array}{c}5-7,5 \mathrm{rel} . \% \\
2,5-7,5 \mathrm{rel} . \%\end{array}$ \\
\hline $\mathrm{P}_{2} \mathrm{O}_{5}$ & MSZ 20135:1999 & $\begin{array}{l}\text { ICP, Thermo Jarrell Ash } \\
\text { ICAP } 61 \mathrm{E}\end{array}$ & $2,5-5$ rel. $\%$ \\
\hline $\mathrm{K}_{2} \mathrm{O}$ & MSZ 20135:1999 & $\begin{array}{l}\text { ICP, Thermo Jarrell Ash } \\
\text { ICAP 61E }\end{array}$ & $2,5-5$ rel. $\%$ \\
\hline $\mathrm{Na}$ & MSZ 20135:1999 & $\begin{array}{l}\text { ICP, Thermo Jarrell Ash } \\
\text { ICAP 61E }\end{array}$ & $4-7,5$ rel. $\%$ \\
\hline$\left(\mathrm{NO}_{3}+\mathrm{NO}_{2}\right)-\mathrm{N}$ & MSZ 20135:1999 & FIAstar, TECATOR & $5-10$ rel.\% \\
\hline $\mathrm{Mg}$ & MSZ 20135:1999 & $\begin{array}{l}\text { ICP, Thermo Jarrell Ash } \\
\text { ICAP 61E }\end{array}$ & 2,5-5 rel.\% \\
\hline $\mathrm{SO}_{4}-\mathrm{S}$ & MSZ 20135:1999 & $\begin{array}{c}\text { ICP, Thermo Jarrell Ash } \\
\text { ICAP } 61 \mathrm{E}\end{array}$ & $2,5-5$ rel. $\%$ \\
\hline $\mathrm{Zn}$ & MSZ 20135:1999 & $\begin{array}{c}\text { ICP, Thermo Jarrell Ash } \\
\text { ICAP } 61 \mathrm{E}\end{array}$ & $5-10$ rel. $\%$ \\
\hline $\mathrm{Cu}$ & MSZ 20135:1999 & $\begin{array}{l}\text { ICP, Thermo Jarrell Ash } \\
\text { ICAP } 61 \mathrm{E}\end{array}$ & $5-10$ rel.\% \\
\hline $\mathrm{Mn}$ & MSZ 20135:1999 & $\begin{array}{c}\text { ICP, Thermo Jarrell Ash } \\
\text { ICAP } 61 \mathrm{E}\end{array}$ & $4-7,5$ rel. $\%$ \\
\hline
\end{tabular}


A területre évenként mintegy $700 \mathrm{~mm}$ mennyiségü vizet öntöztünk.

A betakarítás időtartalma 2011-ben négy hónap, 2012-ben két és fél hónap, 2013-ban pedig három hónap volt. A paprika termésminőségére vonatkozó szabvány szerint (MSZ 11 894-19 888) értékeltük a terméseket és mértük a piacképes (extra, I., valamint II. osztályú) termések átlagtömegét. A szedések alkalmával felmértük a növény habitusát és az egészségi állapotát is.

Az állomány lekerülésekor a talaj felső $30 \mathrm{~cm}$-es rétegéből - ismétlésenként három különböző távolságban lévő pontról - talajmintát szedtünk, amiket kezelésenként külön-külön alaposan elkevertünk, s az ebből nyert átlagmintákat vizsgáltuk. A laboratóriumi vizsgálatokat a vonatkozó Magyar Szabványok szerint végeztük (3. táblázat). A kezelt, illetve a kontroll minták mérési eredményeit egytényezős varianciaanalízissel $(\mathrm{p}<0,05)$ értékeltük.

\section{Eredmények}

\section{Laboratóriumi eredmények}

A cink mennyisége a kezelt talajban 2011-ben $2 \%$-kal $\left(3,46 \mathrm{mg} \cdot \mathrm{kg}^{-1}\right), 2012$-ben $11 \%$-kal $\left(3,54 \mathrm{mg} \cdot \mathrm{kg}^{-1}\right)$ nött, 2013-ban viszont 7\%-kal $\left(2,68 \mathrm{mg} \cdot \mathrm{kg}^{-1}\right)$ csökkent a kontrollhoz képest (kontroll: $3,04,2,74$, illetve $2,88 \mathrm{mg} \cdot \mathrm{kg}^{-1}$ ).

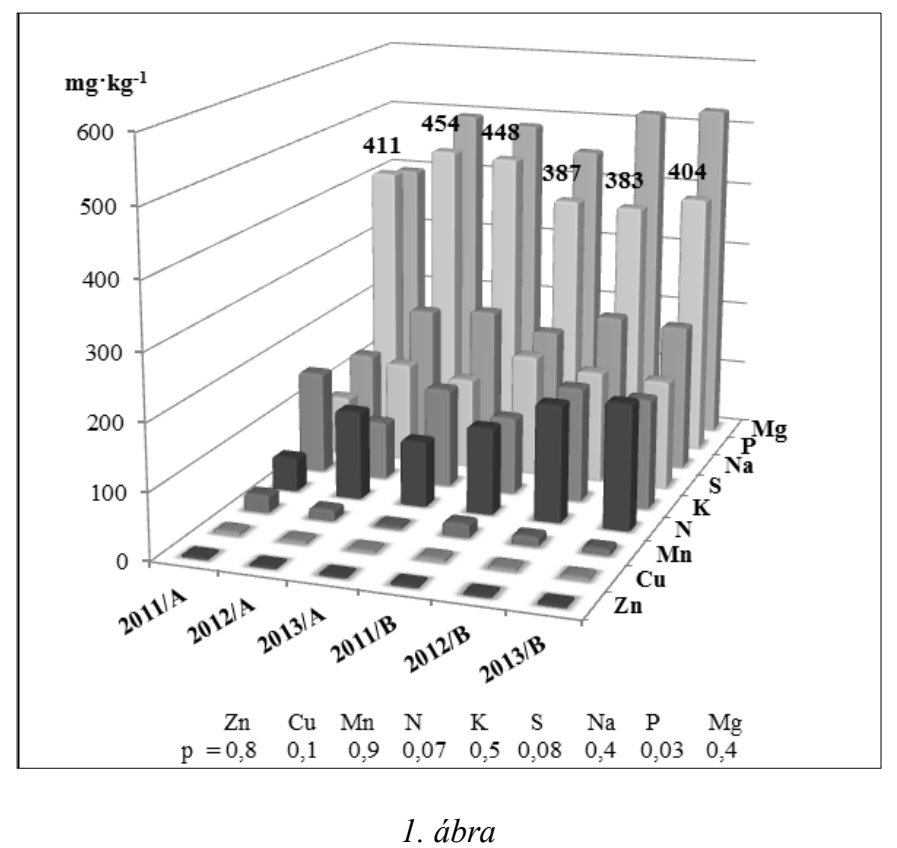

Talaj tápelem- és nátriumtartalma (Sárszentmihály; 2011, 2012, 2013)

Jelmagyarázat: $A$ a kezelt; $B$ a kontroll. A p-értékek (az egytényezős varianciaanalízis ANOVA teszt) a három év adatai alapján számítottak 
A cinkhez hasonlóan változott a talaj réz- és mangántartalma. A preparátummal kezelt talaj Cu-tartalma 2011-ben 8\%-kal (5,59 $\left.\mathrm{mg} \cdot \mathrm{kg}^{-1}\right)$, 2012-ben pedig 13\%-kal $\left(4,6 \mathrm{mg} \cdot \mathrm{kg}^{-1}\right)$ több, majd 2013-ban 28\%-kal $\left(3,72 \mathrm{mg} \cdot \mathrm{kg}^{-1}\right)$ kevesebb, mint a kontroll (kontroll: $5,15,4,06$, illetve $4,76 \mathrm{mg} \cdot \mathrm{kg}^{-1}$ ). A Mn-tartalom a kezelt talajnál kezdetben 30\%-kal (26,8 mg $\left.\mathrm{kg}^{-1}\right)$, később $17 \%$-kal $\left(16,5 \mathrm{mg} \cdot \mathrm{kg}^{-1}\right)$ növekedett, a harmadik évben viszont $227 \%$-kal $\left(4,08 \mathrm{mg} \cdot \mathrm{kg}^{-1}\right)$ csökkent a kontrollhoz képest (kontroll: $\left(20,6,14,1\right.$, illetve $\left.9,28 \mathrm{mg} \cdot \mathrm{kg}^{-1}\right)$. A vizsgált mikroelemek mennyisége a kísérlet első két évében nőtt, később csökkent. A talaj $\mathrm{Zn}$ - $(\mathrm{p}=0,08), \mathrm{Cu}-(\mathrm{p}=0,1)$ és Mntartalma $(\mathrm{p}=0,9)$ a kezelések között nem tér el szignifikánsan.

A kezelt talaj N-tartalma minden évben kisebb volt a kontrolléhoz képest, azonban ezek az eltérések sem voltak szignifikánsak $(\mathrm{p}=0,07)$. A K-tartalom kezdetben $33 \%$-kal $\left(156 \mathrm{mg} \cdot \mathrm{kg}^{-1}\right)$ növekedett, majd $97 \%$-kal $\left(88 \mathrm{mg} \cdot \mathrm{kg}^{-1}\right)$, illetve $42 \%$-kal (151 mg $\left.\mathrm{kg}^{-1}\right)$, csökkent a kontrollhoz képest (kontroll: 117,174 és $167 \mathrm{mg} \cdot \mathrm{kg}^{-1}$ ). Az eltérés ez esetben sem szignifikáns $(\mathrm{p}=0,05)$. A kezelt talaj foszfortartalma minden évben nagyobb volt, mint a kontrollé. A vizsgálat első évében (2011) a kezelt talaj P-tartalma 6\%-kal (411 $\left.\mathrm{mg} \cdot \mathrm{kg}^{-1}\right)$, a második évben $18 \%-\mathrm{kal}\left(454 \mathrm{mg} \cdot \mathrm{kg}^{-1}\right)$, a harmadik évben több mint $10 \%-\mathrm{kal}^{-1}\left(448 \mathrm{mg} \cdot \mathrm{kg}^{-1}\right)$ haladta meg a kontrollét (kontroll: 387,383 , illetve $404 \mathrm{mg} \cdot \mathrm{kg}^{-1}$ ). A talaj P-tartalma szignifikánsan eltér a két kezelés között $(\mathrm{p}=0,03)$.

A kezelt talajok mezoelemtartalma a vizsgálat során alapvetően csökkent. A talajok kéntartalma minden évben kisebb volt, mint a kontrollé. Az eltérések azonban nem szignifikánsak $(\mathrm{p}=0,08)$. A talaj Mg-tartalma a kezelt kísérletben 2011-ben 12\%-kal (397 mg $\left.\cdot \mathrm{kg}^{-1}\right)$, 2012-ben 4\%-kal (495 mg $\mathrm{kg}^{-1}$ ), később 2013-ban 8\%-kal $\left(485 \mathrm{mg} \cdot \mathrm{kg}^{-1}\right)$ volt kisebb a kontrollhoz képest (kontroll: 448 , 517, illetve 527 $\left.\mathrm{mg} \cdot \mathrm{kg}^{-1}\right)$. A talaj Mg-tartalma szignifikánsan különbözött a kezelések között $(\mathrm{p}=0,04)(1$. ábra $)$.

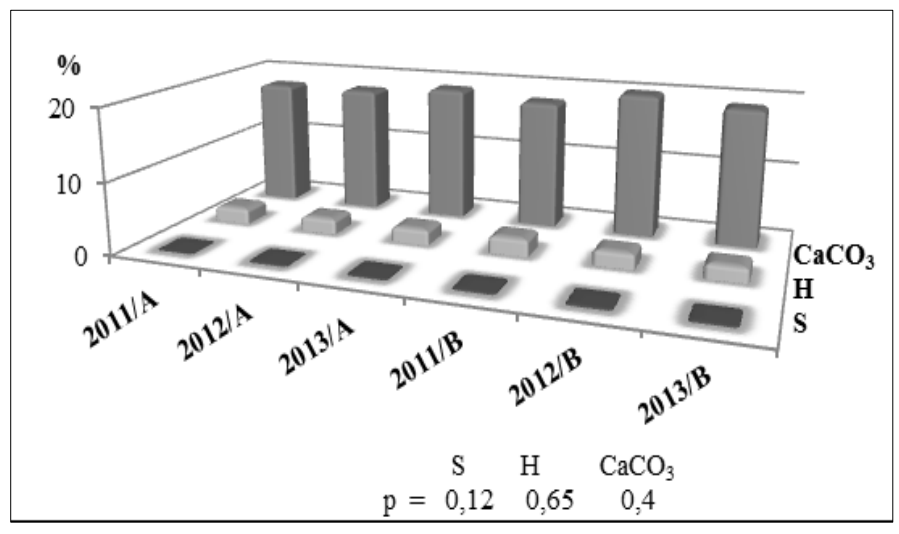

2. ábra

A talaj só-, humusz-, és kalcium-karbonát tartalma (Sárszentmihály; 2011, 2012, 2013) Jelmagyarázat: $A$ a kezelt; $B$ a kontroll; az $S$, a $\mathrm{H}$ és a $\mathrm{CaCO}_{3}$ az összes só, a humusz- és a kalcium-karbonát tartalom. A p-értékek (az egytényezös varianciaanalízis - ANOVA teszt) a három év adatai alapján számítottak 
A kezelt területen az összes sótartalom 2011-ban $(0,11)$ ami 81\%-kal, majd 2012-ben (0,2) 15\%-kal, később, 2013-ban (0,16) 25\%-kal volt kisebb a kontrollhoz képest (kontroll: 0,2, 0,23, illetve 0,2). Ugyanakkor a kezelések között nincs szignifikáns különbség ( $\mathrm{p}=0,12)$ (2. ábra).

A talaj humusztartalma az első évben $(2,26) 8 \%$-kal, $(2,48)$ csökkent, a második évben nem változott, majd a harmadik évben $(2,2)$ 4\%-kal, $(2,1)$ növekedett a kontrollhoz képest. A kezelések között $(\mathrm{p}=0,65)$ nem volt szignifikáns eltérés. A talaj kalcium-karbonát tartalma a vizsgálat ideje alatt a kezelt, ill. kontroll esetében is 18-20\%-os körül mozgott, azonban szignifikáns különbség $(\mathrm{p}=0,4)$ itt sem mutatkozott a kezelések között.

\section{Termesztési eredmények}

A preparátummal kezelt növények termésátlaga minden évben nagyobb volt a kontrollhoz képest. 2011-ben a kezelt növények termése $12 \%$-kal $\left(10,2 \mathrm{~kg} \cdot \mathrm{m}^{-2}\right)$, 2012-ben 46\%-kal $\left(4,1 \mathrm{~kg} \cdot \mathrm{m}^{-2}\right)$, 2013-ban pedig $30 \%$-kal $\left(5,1 \mathrm{~kg} \cdot \mathrm{m}^{-2}\right)$ több volt, mint a kontroll (kontroll: $9,1,2,8$, illetve $3,9 \mathrm{~kg} \cdot \mathrm{m}^{-2}$ ). Az első év kivételével a kezelések között szignifikáns a különbség $(\mathrm{p}<0,05)$. Azonos jelenség volt megfigyelhető az értékesíthető és az extra minőségü terméseknél (3. ábra).

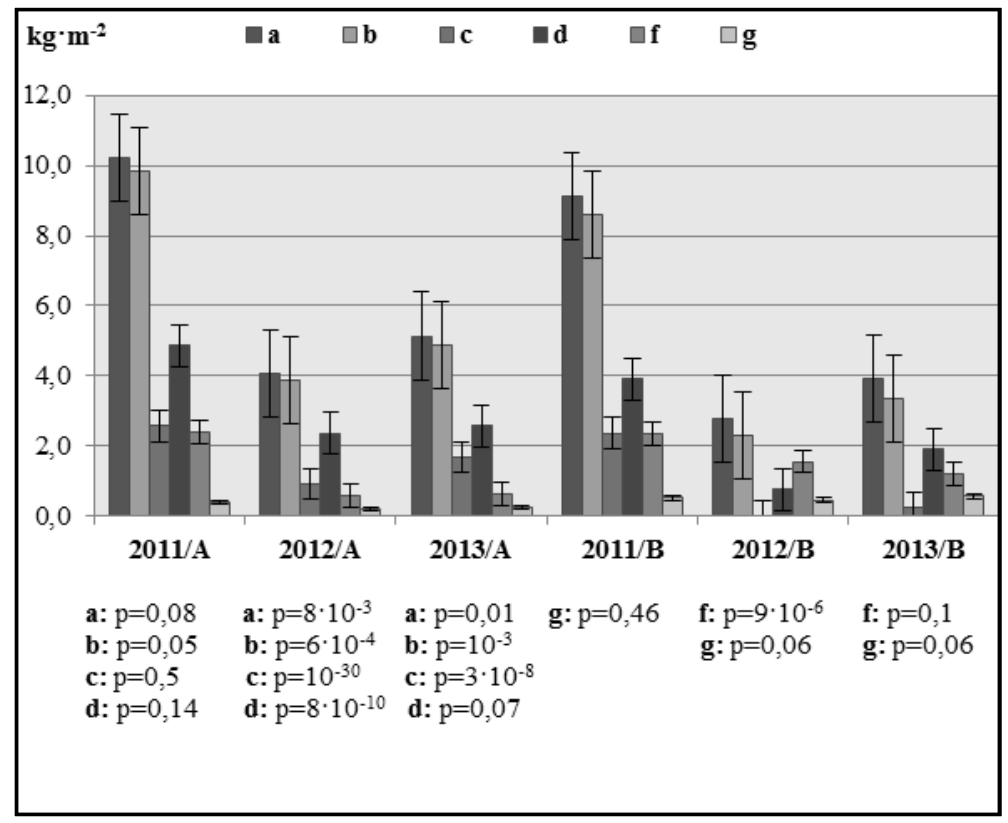

3. ábra

Az átlagtermések alakulása osztályonként (Sárszentmihály; 2011, 2012, 2013)

Jelmagyarázat: A. a kezelt; B. a kontroll; a) az összes; b) a piacképes; c) az extra; d) az I.osztály; e) a II. osztály és f) a selejt. A p-értékek (az egytényezős varianciaanalízis ANOVA teszt) a három év adatai alapján számítottak 
$\mathrm{Az}$ értékesíthetö/piacképes termések a kezelt kísérletben, 2011-ben, 14\%-kal $\left(9,8 \mathrm{~kg} \cdot \mathrm{m}^{-2}\right), 2012$-ben $69 \%$-kal $\left(3,9 \mathrm{~kg} \cdot \mathrm{m}^{-2}\right), 2013$-ban $48 \%$-kal $\left(4,9 \mathrm{~kg} \cdot \mathrm{m}^{-2}\right)$ haladták meg a kontrollét (kontroll: $8,6,2,3$, illetve $4,9 \mathrm{~kg} \cdot \mathrm{m}^{-2}$ ).

A kísérlet során - minden évben - a preparátummal kezelt növények adták a legtöbb extra minőségü termést. A kezeltekben az extra termés négyzetméterenként $0,2 \mathrm{~kg}$-al $(\mathrm{p}=0,5)$, a második évben $0,9 \mathrm{~kg}$-al $\left(\mathrm{p}=10^{-30}\right)$ majd a harmadik évben $1,5 \mathrm{~kg}-\mathrm{al}\left(\mathrm{p}=3 \cdot 10^{-8}\right)$ haladta meg a kontrollét. Az extra termésekhez hasonlóan minden évben a kezelt parcellák adták a legtöbb I. osztályú termést. A kezelt talajok 2011-ben az I. osztályú termésekből négyzetméterenként $1 \mathrm{~kg}$-al $(\mathrm{p}=0,14)$, majd 2012-ben 1,6 kg-al $\left(\mathrm{p}=8 \cdot 10^{-10}\right) 2013$-ban pedig $0,7 \mathrm{~kg}$-al $(\mathrm{p}=0,07)$ adtak több termést a kontrollhoz képest.

Az I. osztályú termések közül csak a 2012-es év termése tér el szignifikánsan a többi év termésétől $\left(\mathrm{p}=8 \cdot 10^{-10}\right)$. Ehhez hasonlóan a II. osztályú termések között is a második évben volt szignifikáns különbség a kezelések között. A kezelt parcellákról négyzetméterenként szedett II. osztályú termés mennyisége 2011-ben nem változott $(\mathrm{p}=1)$ a kontrollhoz viszonyítva, de 2012-ben $1 \mathrm{~kg}$-al $\left(\mathrm{p}=9 \cdot 10^{-6}\right)$, majd 2013-ban 0,6 $\mathrm{kg}$-al $(\mathrm{p}=0,1)$ volt kevesebb a termés a kontrollhoz képest. A legtöbb selejt terméstömeget minden évben a kezeletlen kontroll növények adták. Szignifikáns eltérést nem tapasztaltunk a két kezelés között. 2011-ben négyzetméterenként a kezelt növények $0,1 \mathrm{~kg}$-al $(\mathrm{p}=0,46)$ később, 2012-ben, valamint 2013-ban is, 0,3 kg-al $(\mathrm{p}=0,06)$ adtak kevesebb selejt /értékesíthetetlen termést.

A kezelt parcellákon nevelt növények extra bogyóinak átlagtömege 2011-ben $(168 \mathrm{~g})$ 12\%-kal $\left(\mathrm{p}=3 \cdot 10^{-6}\right)$ nagyobb, majd 2013-ban (150 g) 1\%-kal ( $\left.\mathrm{p}=1\right)$ kisebb volt, mint a kontroll parcellán termesztett növényeké. Az extra osztályban csak a kísérlet első éve adott szignifikáns különbséget (3. ábra).

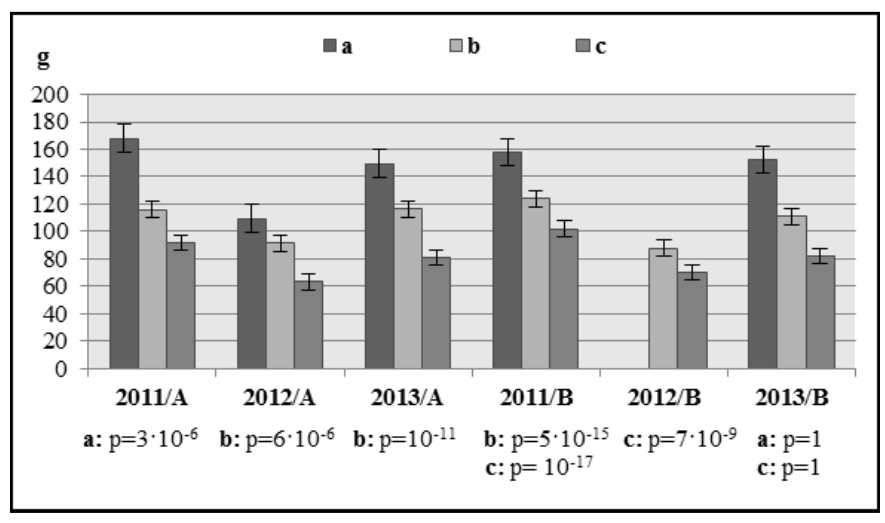

4. ábra

A termések átlagtömegének az alakulása az osztályonként (Sárszentmihály; 2011, 2012, 2013) Jelmagyarázat: A. a kezelt; B. a kontroll; a) az extra; b) az I. osztály és c) a II. osztály. A p-értékek (az egytényezős varianciaanalízis - ANOVA teszt) a három év adatai alapján számítottak 
Az I. osztályú termések átlagtömege a kezelt parcellákban 2011-ben 7\%-kal (116g) $\left(\mathrm{p}=5 \cdot 10^{-15}\right)$ kisebb, később 2012-ben $(92 \mathrm{~g}) 4 \%$-kal $\left(\mathrm{p}=6 \cdot 10^{-6}\right)$ nagyobb, majd 2013-ban $(111 \mathrm{~g})$ ismét $4 \%$-kal $\left(\mathrm{p}=10^{-11}\right)$ nagyobb a kontrollhoz képest. A kezelések között minden évben szignifikáns volt a különbség. A kezelt II. osztályú termések átlagtömege a kísérlet első évében (92 g) 10\%-kal $\left(\mathrm{p}=10^{-17}\right)$, a második évben $(63 \mathrm{~g}) 11 \%$-kal $\left(\mathrm{p}=7 \cdot 10^{-9}\right)$, a harmadik évben pedig $(81 \mathrm{~g}) 1 \%$-kal $(\mathrm{p}=1)$ volt kisebb, mint a kontrollé (4. ábra).

A kezelésben részesített növényeken gyorsabb növekedést, jobb vitalitást, megújuló képességet, valamint kiegyensúlyozottabb vegetatív-generatív habitust figyeltünk meg a kontrollhoz viszonyítva. A vizsgálatokat követő évben (2014) a preparátum többéves használatából adódó utóhatás jelentkezett a területen. A kezelésben részesített területen a növények jobb kondíciójúak voltak (5. ábra).

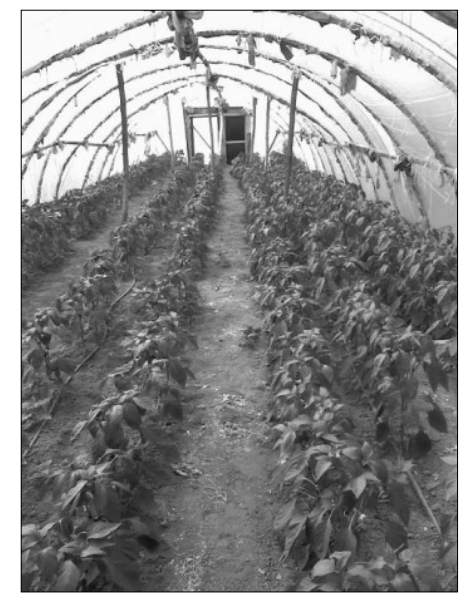

5. ábra

A preparátum utóhatása a kísérletet követő évben. Balra négy sor a kontroll, jobbra négy sor a kezelt terület (Sárszentmihály, 2014) (Fotó: Németh T.)

\section{Következtetések}

Az Amalgerol biopreparátum kezdetben növelte a talajban lévő ( $\mathrm{Zn}, \mathrm{Cu}$, és $\mathrm{Mn}$ ) mikrolemek mennyiségét, azonban a vizsgálat utolsó évében növekedést nem tapasztaltunk. Úgy gondoljuk, hogy hosszú távon a csökkenés azzal magyarázható, hogy előző években a kezelt parcellák magas termésátlagai miatt a növények kimeríthették a talaj mikroelem készletét. Hipotézisünk szerint ezzel magyarázható a talaj kálium-, magnézium-, kén és részben a nitrogén tartalmának a csökkenése is. Feltételezésünk alapján azonban a preparátum emelheti a talaj mikroelem készletét, mert a 2011-ben tapasztalt - a hideghajtatásban viszonylag nagy $-9-10 \mathrm{~kg} \cdot \mathrm{m}^{-2}$ feletti átlagtermés ellenére, a kezelt talaj mikroelem tartalma nagyobb volt a kontrollhoz képest. 
A kezelt talaj nitrogén tartalma csökkent a vizsgálat alatt. Megítélésünk szerint a kezelések hatására sokkal intenzívebbé vált a talaj mikrobiális - különösen a lebontó mikroszervezetek - tevékenysége, ennek eredményeképpen pedig fokozódott a lebontást segítő mikroorganizmusok nitrogénszükséglete.

A preparátummal történő kezelések kedvező hatással voltak a talaj foszfor háztartására. A talaj foszfortartalma minden évben emelkedett a kezeletlen kontrollhoz képest. E folyamat annak ellenére végbement, hogy a területen jelentősebb foszfortágyázást végeztünk volna. Az emelkedés azzal magyarázható, hogy a termék vélhetően aktivizálta a foszformobilizáló mikroorganizmusokat, így a szerves foszforanyagok kerültek a talajoldatba, szignifikánsan növelve ezzel a talaj foszfor tartalmát. Hasonló jelenségeket figyeltek meg RicHTER és munkatársai (2002). Ugyanakkor RICHTER és munkatársai (2002) kísérleti tapasztalataival ellentétben megfigyeléseink szerint a készítmény nem befolyásolta a talaj kálium- és magnéziumtartalmát.

A preparátum nem volt hatással a talaj kéntartalmára. A kezelt talaj összes sótartalmának csökkenése vélhetően a talaj kálium-, magnézium-, kén- és a nitrogéntartalmának csökkenésével hozható összefüggésbe. A kezelt talaj humusztartalma kezdetben szintén csökkent, majd változatlan volt az utolsó évben pedig kissé emelkedett. A hosszú távú használat feltételezhetően kedvező hatású még szerves trágya alkalmazása nélkül is, azonban véleményünk szerint a biopreparátum hatékonysága - szerves anyagok alkalmazása mellett - még kedvezőbb lehet. Álláspontunk szerint - RICHTER és munkatársainak (2002) vizsgálati eredményeivel szemben - a termék a talaj kalcium-karbonát tartalmára nincs hatással. Véleményünk szerint a talajban lejátszódó kedvező folyamatok (foszfor feltáródás, élénkebb szervesanyag-bontás, stb.) a preparátum talajélénkítő hatásával hozhatók összefüggésbe, amelyről RichTER és munkatársai (2002) is beszámolnak kutatási eredményeikben.

Az Amalgerol kezelések hatására minden évben nőtt a termés. A készítmény hatékonyan befolyásolta a növények piacképes termését ezen belül is az extra, valamint az I. osztályú termések részarányát. A kezelések eredményeként nőtt a minőségi hozam, ugyanakkor csökkent a kevésbé piacképes (II. osztályú, selejt) termések mennyisége. A kezelések megnövelték a bogyók átlagos tömegét. Hasonló eredményekről számol be BOTEVA (2014) is. Tapasztalatai alapján a termék elsősorban a minőségi termések (extra és az I. osztályú) átlagtömegét növelte. A kezelések hatására javult a növények kondíciója, stressztürő-képessége és gyorsabb lett a növekedésük. A növények kielégítően kötöttek még a kései idöszakban is. Véleményünket tapasztalataink alapján fogalmazzuk meg. Elméletünk szerint a preparátumban lévő hatóanyagok stimuláló hatást fejtettek ki a mikorrhiza gombákra. Hasonló feltételezésről írnak PARÁDI és munkatársai (2014) is. A stimuláló hatás következtében fokozódott a tápanyagfelvétel melynek köszönhetően - még a nagy nátrium tartalmú talajon is - nőtt a hozam, valamint javult a termések minősége és a növények stressztürö képessége.

A kutatásainkat követően 2014-ben vizsgáltuk a növények kondicionális állapotát azokban a parcellákban, ahol az elmúlt években kezeléseket végeztünk. 
Vizsgálati eredményeink alapján a készítmény többéves használat során javíthatja az utóvetemény kondícióját. Véleményünk szerint a preparátum segítségével szigorú termesztés technológiai fegyelem mellett - még kedvezőtlen adottságú talajokon is lehetséges minőségi termelés. Úgy gondoljuk, hogy az Amalgerol, valamint egyéb biostimulátorok használatával környezetkímélő módon növelhető a növények termöképessége, azonban további vizsgálatokat is szükségesnek tartunk a termék feltételezett humusz, illetve mikroelemtartalom-növelő hatásának felderítése érdekében.

\section{Összefoglalás}

A hajtatás során a túlzott mütrágya-használat problémákat okozhat. Célul tüztük ki az Amalgerol talaj- és növénykondicionáló preparátum hatásának feltárását nagy sótartalmú talajon paprikahajtatásban. A preparátumot in vivo (termesztési), valamint in vitro (laboratóriumi) körülmények között vizsgáltuk három éven keresztül (2011-2013). Laboratóriumi körülmények között a talaj kémhatását, továbbá, a tápanyag, humusz-, kalcium-karbonát-, só-, valamint nátriumtartalmát vizsgáltuk. Termesztési körülmények között a növényekre gyakorolt hatást értékeltük monokultúrában. A kisparcellás kísérlethez két kezelést (kezelt, ill. kezeletlen kontroll) állítottunk be.

A preparátumos kezelések hatására szignifikánsan növekedett a talaj foszfortartalma, azonban a készítmény nem növelte a talaj kálium-, magnézium-, kén- és kalciumtartalmát. A termék használata feltételezhetően növeli a talaj mikroelem valamint humusztartalmát. Feltételezéseink szerint a preparátum pozitív hatást gyakorol a talaj mikroflórájára, ennek köszönhetően pedig kedvező folyamatok (pl. foszfor feltáródás, humusztartalom növekedés) alakulnak ki a talajban. Úgy véljük, hogy szervestrágyázással kombinálva a preparátum hatékonysága növelhető. A készítmény kedvezően befolyásolta a termések mennyiségét és minőségét, különösen az értékesíthető termések tömegét növelte jelentősen. A preparátum a termések darabosságára is kedvező hatású volt azáltal, hogy növekedett a minőségi extra valamint az I. osztályú termések átlagtömege. A preparátumos kezelések hatására javult a növényi kondíció és az általános ellenálló képesség.

Feltevésünk szerint a termék szinergista módon indukálja a gyökér-gomba ún. arbuszkuláris mikorrhiza (AMF) gomba kapcsolatokat. A mikorrhizáció eredményeként pedig a növény nagyobb tápanyag- és vízfelvétele képes, ezáltal növekszik a növények termésprodukciója, valamint javul a stressztürö-képessége. Tapasztalataink alapján úgy látjuk, hogy a preparátum hatékonyan használható a mezőgazdasági termelésben.

Köszönettel tartozunk a Cheminova FMC magyarországi vállalatának, amely kísérletünk lefolytatásához anyagi támogatást és szaktanácsadást nyújtott.

Kulcsszavak: biopreparátum, paprikahajtatás, magas sótartalom, monokultúra 


\section{Irodalom}

BAum, C., El-Tohamy, W., \& Gruda, N., 2015. Increasing the productivity and product quality of vegetable crops using arbuscular mycorrhizal fungi: A review. Scientia Horticulturae. 187. 131-141.

Boteva, H., 2014. Optimizing of systems for nutrition in biological pepper production. Turkish Journal of Agricultural and Natural Sciences. 1. (2) 1665-1670.

CACIKOVA, J., 1997. Vliv připravku AMALGEROL na pudni mikroorganismy, Diplomová práce (145/48/97) Agronomická fakulta Mendelovy zemědělské a lesnické university v Brně. Brno.

Cordier, C., Pozo, M. J., Barea, J. M., Gianinazzi, S., \& Gianinazzi-Pearson, V., 1998. Cell defense responses associated with localized and systemic resistance to Phytophthora parasiticainduced in tomato by an arbuscular mycorrhizal fungus. Molecular Plant-Microbe Interactions. 11. (10) 1017-1028.

Davies, F. T., JR. PotTer, J. R. \& Linderman, R. G., 1992. Mycorrhiza and repeated drought exposure affect drought resistance and extraradical hypha development of pepper plants independent of plant size and nutrient content. Plant Physiology. 139. (3) 289-294.

Delchev, G. \& Stoyanova, A., 2013. Changes at the sowing properties of the durum wheat sowing-seeds by use of foliar fertilizers, stimulators and antitranspirants. Science \& Technologies. 3. (6) 213-218.

Derkowska, L., Paszt, S., Harbuzov, A. \& Sumorok, B., 2015. Root Growth, Mycorrhizal Frequency and Soil Microorganisms in Strawberry as Affected by Biopreparations. Advances in Microbiology. 5. (1) 65-73.

Dobos A., Víg R., MolnÁR K. \& NAGY J., 2011. Természetes alapanyagú lombtrágyák hatékonysága szabadföldi kísérletekben: II. Burgonya (Solanum tuberosum L.). Növénytermelés. 60. (1) 27-42.

Elena, J., \& Vytautas, L., 2013. Effect of the biological preparations Azofit and Amalgerol on sugar beet seeding. Proceedings of the International Scientific Conference. 6. (2) 106-110.

Fora, C. G., StanciU, S., MoATĂR, M., BanU, C. \& Ştefan, C., 2015. The influence of bio-effectors on oil seed rape, winter wheat, sun-flower and maize crop production. Agricultural Science. 47. (2) 56-61.

Füzy, A., Biró, B., Tóth, T., HildebrandT, J. \& Bothe, H., 2008. Drought, but not salinity determines the apparent effectiveness of halophytes colonized by arbuscular mycorrhizal fungi. Journal of Plant Physiology. 165. 1181-1192.

HALLER G., 2015. Növényvédő szerek termésnövelő anyagok II. Agrinex Kiadó. Budapest.

HeCKMAN, J. R., 1993. Effect of an organic biostimulant on cabbage yield. Journal of Home \& Consumer Horticulture. 1. (1) 111-113.

Kostadinova, S., Kalinova, St., Hristoskov, A., \& Samodova, A., 2015. Efficiency of Some Foliar fertilizers in Winter Wheat. Bulgarian Journal of Agricultural Science. 21. (4) 742-746.

MARSCHNER, H. \& Dell, B., 1994. Nutrient uptake in mycorrhizal symbiosis. Plant and Soil. 159. (1) 89-102. 
Milev, G. \& Todorova, R., 2014. Effect of the complex suspension foliar fertilizers Lactofol and Amalgerol premium on grain yield from soybean (Glycine max (L.) Merr.) under the conditions of Dobrudzha region. Agricultural Science and Technology. 6. (4) 445-450.

Nardi, S., Carletti, P., Pizzeghello, D. \& Muscolo, A., 2009. Biological activities of humic substances. In: Biophysico-chemical processes involving natural nonliving organic matter in environmental systems 2. (Eds.: SENESI, N,. XING, B. \& HuANG, P. M.) 305-340. Wiley. ISBN: 978-0-470-41300-5

PARÁdi I., FeKetÉNÉ Palkovics Á. \& Bozsó M., 2014. Az Amalgerol és a mikorrhiza hatása a fotoszintézisre és növekedésre. In: Integrált termesztés a kertészeti és szántóföldi kultúrákban (XXXI.). (Szerk: GÁL, P., NovÁK, R., PÁNCZÉL, M. \& RIPKA, G.) 59-65. Magyar Növényvédelmi Társaság. Budapest.

Pozo, M. J. \& AzCóN-AgUILAR, C., 2007. Unravelling mycorrhiza-induced resistance. Current Opinion in Plant Biology. 10. (4) 393-398.

PULK, M., 2015. Influence of biostimulants on the yield and quality of onion. Thesis. Estonian University of Life Sciences Agricultural and Environmental Sciences. Tartu.

Richter R., Tesarová M., Hrivna L. \& Hlusek J., 2002. Az Amalgerol hatása a talaj termékenységére és néhány szántóföldi kultúra termésére. Agrofórum. 13. (12) $22-25$.

Richter, R., Hlušek, J. \& TeSAŘOvÁ, M., 2005. Pomocné látky ovlivňující biologickou sloţku půdy. In Úroda, sv. č. 53., č. 3., s. 56-57.

Shannon, M. C. \& GRIEve, C. M., 1998. Tolerance of vegetable crops to salinity. Scientia Horticulturae. 78. (1-4) 5-38.

Šimunić, R., Šubić, M., BATAS, D., KRnJaić, S., Jukić, R. \& Rob, K., 2011a. Use of biostimulator amalgerol premium for better qality and higher yield of crops. 7 . Naučno-stručni skup sa međunarodnim učešcem "KVALITET 2011". Neum. B\&H. 707-712.

Šimunić, R., Krnjaić, S., Batas, D., Jukić, R., \& Zovkić, P., 2011b. Effect of biostimulator Amalgerol Premium in soybean (Glicine $\max$ L.) and sunflower (Helianthus annuus L.). 46th Croatian \& 6th International Symposium on Agriculture. Zagreb. (http://sa.agr.hr/pdf/2011/sa2011_a0505.pdf.)

Smith, S. E. \& ReAD, D. J., 1997. Mycorrhizal Symbiosis, $2^{\text {nd }}$ ed. Academic Press. London.

TAKÁCS, T., BiRÓ, B. \& VÖRÖS I., 2006. Response of arbuscular mycorrhizal fungi infectiveness to soil nitrogen supply. Cereal Res. Commun. 34. 319-322.

WHIPPS, J. M., 2004. Prospects and limitations for mycorrhizas in biocontrol of root pathogens. Canadian Journal of Botany. 82. (8) 1198-1227.

Zaidi, A., Ahmad, E., Khan, M. S., SAIF, S. \& Rizvi, A., 2015. Role of plant growth promoting rhizobacteria in sustainable production of vegetables. Current perspective. Scientia Horticulturae. 193. 231-239.

Érkezett: 2015. december 18. 


\title{
Effect of the soil and plant conditioner Amalgerol on peppers grown in monoculture on high salinity soil in a protected cultivation system
}

\author{
${ }^{1}$ T. NÉMETH, ${ }^{2}$ J. HORVATH and ${ }^{3}$ S. KuCSERA \\ ${ }^{1}$ Expert in Plant Protection \\ ${ }^{2}$ Regional Engineer, Cheminova FMC, Hungary \\ ${ }^{3}$ Soil Conservation Laboratory, Directorate for Plant, Soil and Agricultural Environment \\ Protection, National Food Chain Safety Office, Velence
}

\begin{abstract}
Summary
In the course of protected cultivation, the excessive use of fertilizers causes significant problems. The aim of this research was to examine the effect of the plant and soil conditioner Amalgerol on peppers grown on high salinity soils in protected cultivation. The product was tested under in vivo (in greenhouses) and in vitro (in the laboratory) conditions in three years (2011-2013). In the laboratory the soil was analysed for $\mathrm{pH}$ and for its nutrient, humus, calcium carbonate, salt and sodium content. In the greenhouse, the effect of the product on plants was evaluated in monoculture. The experiment consisted of two treatments, Amalgerol application and an untreated control.

Amalgerol treatment led to a significant increase in the soil phosphorus content, but caused no increase in the potassium, magnesium, sulphur or calcium carbonate content. The product is thought to increase the micronutrient and humus content of the soil by exerting a positive effect on the soil microflora, leading to the development of favourable processes (e.g. the release of phosphorus, an increase in humus content) in the soil. It is expected that the effectiveness of the product would be enhanced if used in combination with organic fertilizer.

The product had a positive impact on the quality and quantity of the yield, having an especially significant influence on the weight of marketable peppers. The preparation also increased the mean weight of peppers in the premium and first class quality categories.

The treatment also improved the condition of the plants and their overall resistance. The product is thought to stimulate associations between the plant roots and arbuscular mycorrhizal fungi (AMF), enabling the plants to take up more nutrients and water and leading to increased productivity and stress tolerance. The results suggest that the product could be effectively used in agricultural production.

Table 1. Description of the experiment (Sárszentmihály). (1) Year. (2) Treatment. (3) Plant density $/ \mathrm{m}^{2}$. (4) Row and plant distance, cm. (5) No. of plots. (6) Plant number/plot. (7) Plot size, $\mathrm{m}^{2}$. a) Treated; b) Control.

Table 2. Quantity of nutrients applied (Sárszentmihály). (1) Year. (2) Active ingredients, $\mathrm{g} \cdot \mathrm{m}^{-2}$.

Table 3. Methods used for soil analysis. (1) Soil property. (2) Method (Hungarian standards.) (3) Instrument. (4) Degree of uncertainty. a) Total salt; b) Humus.

Figure 1. Nutrient and sodium content of the soil (Sárszentmihály, 2011, 2012, 2013). Legend: A: treated; B: control; p-value based on single factor analysis of variance (ANOVA) using three years' data.
\end{abstract}


Figure 2. Salt, humus and calcium carbonate content of the Soil (Sárszentmihály, 2011, 2012, 2013). Legend: A: Treated; B: Control; S: Total salt; H: Humus; $\mathrm{CaCO}_{3}$ : calcium carbonate; $p$-value based on single factor analysis of variance (ANOVA) using three years' data.

Figure 3. Mean yield of each quality category (Sárszentmihály, 2011, 2012, 2013). Legend: A. Treated; B. Control; a) Total; b) Marketable; c) Premium; d) First class; e) Second class; f: Substandard; p-value based on single factor analysis of variance (ANOVA) within each year.

Figure 4. Mean pepper weight in each quality category (Sárszentmihály, 2011, 2012, 2013). Legend: A. Treated; B. Control; a) Premium; b) Class I; c) Class II.; pvalue based on single factor analysis of variance (ANOVA) within each year.

Figure 5. Carry-over effect of the product in the following year. The four rows on the left were grown on the control area, and the four rows on the right on the treated area. Sárszentmihály, 2014. (Photo: T. Nemeth) 